\title{
Regional diversity in the socio-economic situation of Poland's rural population in the period 1967-2001, assessed by anthropological methods
}

\begin{abstract}
The analysis covered girls, aged 9-18, from farmer, farmer-worker and nonfarmer rural families inhabiting 4 regions of Poland. Additionally, parents' education, number of children per family and the wealth of the family were recorded. The aim of the study was to assess the impact of social stratification of the rural population, the economic crisis (1978-1989) and political and economic transition (1989) on the girls' biological maturation. Age at menarche and body height were used as biological measures of living conditions. In the period 1967-1977 a marked acceleration in maturation and a significant increase in average body height were noted. The study repeated in 1987 demonstrated negative effects of the economic crisis (1977-1989). Research findings from 2001, after the political system transformation, provide evidence 'compensating for losses' recorded in girls' biological condition during the crisis. The diversity of biogeographic and socioeconomic conditions of rural inhabitants in the studied regions is reflected in a marked diversification in age of menarche and body height.
\end{abstract}

Keywords

Regions of Poland • rural girls • social stratification • economic crisis • age at menarche $\cdot$ body height

(C) University of Warsaw - Faculty of Geography and Regional Studies

\author{
Teresa Łaska-Mierzejewska ${ }^{1}$ \\ Elżbieta Olszewska² \\ ${ }^{1}$ Academy of Sport Education in Warsaw \\ e-mail: terlasmie@gmail.com \\ 2University of Physical Education in Warsaw \\ e-mail: elzbietaawf@o2.pl
}

Introduction

The socio-economic structure of the Polish rural population differs markedly from that existing in many other European countries. Significant economic and political changes affected the inhabitants of villages during the last 50 years of the 20th century. At the end of the 1940s the government introduced land reform. The essential feature of this reform was the expropriation of privately owned land exceeding 50 or 100 ha, depending on the province. Overall, 6 million hectares of land were gratuitously transferred to peasants, and state-owned agricultural farms were established on 4 million of these hectares. Under the communist regime, about $80 \%$ of arable land in Poland was in private hands. Poland was an exception, since in other communist countries people were not allowed to own land. Polish farms were small in area, poorly mechanized, and short of labour, owing to the outflow of rural youth to towns, either to live or to seek employment. When older farmers were no longer fit to till their land, it was transferred to the state institutions for rent in cash, and the children retained only their parents' house, thus creating a group of villagers with no land of their own. According to Sikorska (1992), landless villagers constituted about $20 \%$ of the rural population in $1960,30 \%$ in 1970 , and $41 \%$ by 1988 , with marked differences between regions. Despite such a serious situation, Polish farmers were the main food producers during the entire communist period, because the majority of state-owned agricultural farms showed poor productivity. In spite of their poor economic achievements, state-owned farms offered employment to a high percentage of landless villagers and to the owners of small farms.
During the period 1978-1989, an economic crisis developed. The Polish population was exposed to acute shortages in all kinds of goods. The inhabitants of towns and landless villagers were subjected to rationing of food products, petrol and other industrial products until November 1989. The crisis was not so acute for farmers, the main food producers at that time.

In 1989, the Soviet-style communist system collapsed and the transformation to a free market economy began. In 1991 the state-owned farms were lawfully liquidated, resulting in about 450000 employees losing their jobs (Dzun 1991, 2002a, 2002b). For the provinces where the concentration of state-owned farms was highest, as in the Choszczno region, unemployment grew to $27 \%$ (Michna 2001). At the other end of the social scale, new private owners, who managed to purchase the privatized state-owned properties, became rich very quickly.

\section{The aims of the studies}

The aims of the studies encompassed several changes over the period 1967-2001. In the years 1967 and 1977 the aim was to evaluate the biological effects of social stratification of the rural population from different regions in Poland. In 1987 the aim was to assess the biological effects of the economic crisis on selected groups of the rural population from the regions under study. The aim of studies conducted in 2001 was to evaluate the change in living conditions of the rural population resulting from the political and economic transition in Poland. 


\section{Materials}

Anthropological studies on social stratification of the rura population were initiated by Łaska-Mierzejewska, for the first time in Poland, in 1967 (7 regions, $\mathrm{N}=7889)$ and repeated in 1977 (8 regions, $\mathrm{N}=9827$ ), 1987 (8 regions, $\mathrm{N}=13556$ ) and 2001 (4 regions, N=9599) (Łaska-Mierzejewska 1970, 1983; ŁaskaMierzejewska \& Łuczak 1993; Łaska-Mierzejewska \& Olszewska 2003, 2004, 2006, 2007). In 2001 the research was limited to only four regions due to economic reasons: the region of Choszczno in the Zachodniopomorskie Voivodeship, the region of Ostrów Mazowiecka in the Mazovian Voivodeship, the region of Suwałki in the Podlaskie Voivodeship, and the region of Leszno in the Wielkopolskie Voivodeship.

In order to differentiate between the regions under study, the authors use the names of the main towns of Polish administrative districts from where the samples of girls from rural schools were taken. An important outcome of the studies was to allow follow-up research in the same villages and schools. In some regions, as well as in some communes (villages), the percentage of villagers whose only source of income was farming dropped dramatically between the periods of study. For that reason, studies in some regions were either totally abandoned or continued but with a new choice of other communes characterized by a higher concentration of farmers. The regions of Choszczno and Ostrów had been studied since 1967, thus the research could be repeated four times. The region of Suwałki was included in the research in 1977 with the aim of broadening the fraction of farmers under study, and was examined three times. The region of Leszno was added in 1987. In rural primary schools all girls were studied, whereas in secondary schools only these of rural origin were included. The age range was 9-18 years.

The basic criterion employed in order to group the girls was the source of income in the family. Three groups were established:

1. Farmer families - fully dependent on their own farms,

2. Farmer-worker families - owning a farm of an area at least 1 hectare, with at least one member of the family also employed outside the farm,

3. Non-farmer families, landless villagers.

Parents' education, the number of children per family, household appliances, and the farm size were also recorded.

The biological measures of living conditions were: body height and the age of first menstruation (age at menarche, menarcheal age, AM). The average menarcheal age of investigated girls was determined by status-quo method, and elaborated by probits. The study also evaluated the degree to which the investigated girls were overweight and obese (Chrzanowska et al. 2013).

\section{Anthropological measures of social stratification}

Socioeconomic inequalities observed in most countries, including Poland, have various biological effects reflected by differences in body height and other somatic features in children, youth and adults, as well as differences in maturation rate (Bielicki et. al. 1986, 1997, 2003; Henneberg \& Low 1995; Hulanicka et.al. 1990; Hulanicka \& Waliszko 1991; Komlos 1994; Liestol 1982; Lindgren 1988; ŁaskaMierzejewska 1970, Łaska-Mierzejewska \& Olszewska 2003, 2004, 2006, 2007).

In order for biological features to carry information about the socioeconomic stratification in the population, they must be characterized by a high degree of ecosensitivity, must be easily obtainable from large numbers of study subjects, and objective. The features most frequently used by anthropologists are body height and age at menarche (AM). The extremely high ecosensitivity of the latter feature is proved by the fact that the age of first menstruation comes monotonically later as the number of children in a given family increases: for one child the AM is 13.0 years, for seven or more, the AM is 13.5) (LaskaMierzejewska \& Olszewska 2003).

Some anthropological findings and conclusions have political undertones as they demonstrate biological effects (either positive or negative) of the socioeconomic situation created by the authorities governing the country. Anthropological studies may also show especially adverse living conditions of one or more groups when the biological parameters measured in these groups stand out markedly in comparison to the total number of people under study. In 2001 the biological effects of unemployment among landless villagers were recorded. Daughters of the unemployed in the non-farmer group experienced their menarcheal age by 0.28 years later when compared to all the girls under study, and by 0.38 years later when compared to daughters of employed fathers in the same group. They also demonstrated lower body height by 0.13 SD and 0.16 SD respectively (Olszewska \& ŁaskaMierzejewska 2008). In 2001, daughters of fathers on disability leave demonstrated earlier maturation when compared to all the girls under study, both from the farmer-worker and non-farmer groups (Łaska-Mierzejewska \& Olszewska 2003). The earlier age at menarche of girls from families where fathers were on disability leave was also recorded by Hulanicka (1986) and Popczyk (1990). The fathers of the studied girls were relatively young and the disability benefit they were receiving was probably not their only income.

\section{Monitoring changes in the socio-economic situation of Poland}

Social inequality among Polish rural inhabitants, present in society for a long time, underwent several changes over the study period. The decade 1967-1976 was a period of 'in credit' prosperity, which was reflected by a significant improvement in living conditions as compared to the previous period. An intensive increase in mean body height and an intensive acceleration in maturation of the girls under study were recorded. The period 1977-1989 saw an acute economic crisis, which diminished or even arrested the process of body height increase and decelerated maturation. In our investigations, held in 1987, we recorded both phenomena, with varying degrees of intensity, in girls from farmer families and landless rural families. The deterioration of living conditions in the 1980s affected not only the Polish population, but also others under a similar political and economic system. A delay in menarcheal age was recorded in Bulgarian girls (Stoev 1994) and in girls from Moscow (Yampolskaya 1994; Godina 1994).

The political and economic transformation of the year 1989 , resulting in the legal abolition of state-owned agricultural enterprises in 1992, had a varied impact on different groups of rural inhabitants in different regions of Poland. The stateowned agricultural enterprises offered work to landless villagers - their dissolution caused mass unemployment and a dramatic deterioration of the socio-economic situation (Dzun 1991, 2002a, 2002b; Michna 2001; Olszewska \& Łaska-Mierzejewska 2008). Fig. 1 presents differences in age at menarche of girls from the specified groups in the rural population.

Throughout the period under study the earliest maturation was experienced by girls from non-farmer families, then by daughters from families with two sources of income, and the latest by girls from typical farmer families. The last group was characterized by lower educational status of parents, more multiple-child families and poorer ownership of durable household goods. As the result of worse living conditions, rural inhabitants in this group were continuously abandoning farming as the only source of income, which made it increasingly difficult to obtain a satisfactory number of girls for the research. The differences in maturation rate of girls 


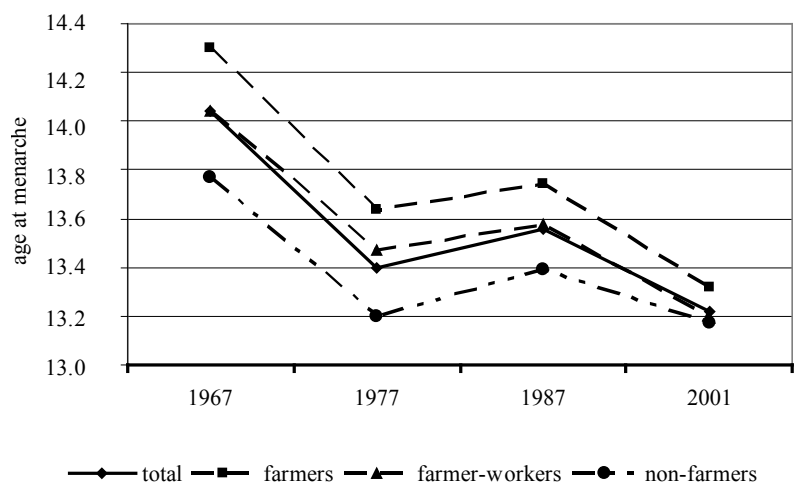

Fig. 1. Average age at menarche of girls from farmer, farmerworker and non-farmer families in the years 1967-2001

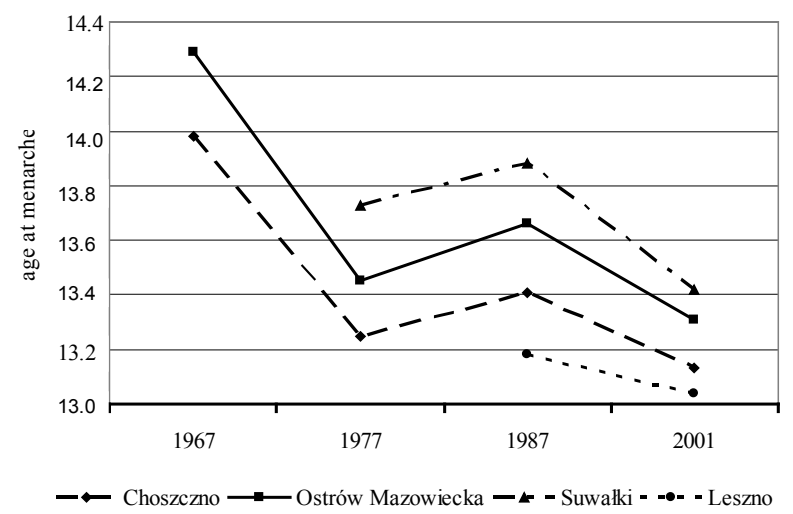

Fig. 2. Average age at menarche of rural girls in different regions of Poland in the years 1967-2001

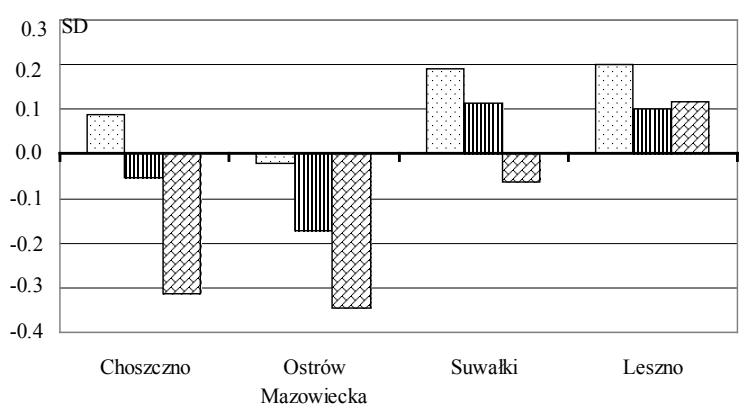

$\square$ 1-2 children $\square$ 3-4 children $\square 5$ or more children

Fig. 3. Z-score values of body height of rural girls in different regions of Poland according to number of children per family in 2001

from farmer and non-farmer families decreased in consecutive investigations, from 0.53 years in 1967 to 0.15 years in 2001 . Over the period 1967-2001 the biggest acceleration in maturation, amounting to 0.98 years, was noted in farmers' daughters. The girls from the farmer-worker group demonstrated a slightly lower figure ( 0.85 years), whereas the lowest acceleration, 0.6 years, was observed in girls from landless families (Fig.1). In the region of Choszczno, differences were even greater: the acceleration in maturation of girls in the farmer group amounted to 1.24 years, while in the non-farmer group it was only 0.52 years. Based on these findings it may be argued that, in the period 1967-2001, the biggest civilisational leap and improvement in living conditions were experienced by farmer families.
The acceleration of biological development or the lowering of menarcheal age, and the secular trends in height and weight are phenomena well known all over the world and are attributed to a betterment of living conditions in the population (De Muinck, Keizer-Schrama \& Mul 2001).

Social gradients of maturation rate over the period 19672001 varied in value but not in direction. The earlier the age at menarche was observed:

- the less the family depended on farming as the only source of income (except for the region of Choszczno in 1987 and 2001),

- the smaller the number of children per family,

- the higher the educational status of parents,

- the bigger the farm,

- the better the household was equipped with consumer durables.

Anthropological measures of living conditions in the regions under study

The recorded differences among inhabitants of the regions under study refer to social structure, measured by source of income, number of children per family, educational status of inhabitants (Tab. 1), size of farms, ownership of durable household goods, and unemployment rate. The regions also vary in weather conditions, industrialization, density and quality of roads, and agriculture. The differences are reflected in the anthropological measures of the socio-economic situation, maturation rate (Tab. 2) and body height of the girls. The dependencies were discussed in detail in previous articles: Łaska-Mierzejewska \& Olszewska 2004, 2006.

\section{The region of Choszczno}

The region of Choszczno demonstrates the most spectacular changes in the socio-economic situation of rural inhabitants. The percentage of farmers decreased consistently from $42 \%$ in 1967 to $18 \%$ in 2001 , whereas the share of landless inhabitants increased from $38 \%$ to over $60 \%$. Over $50 \%$ of cultivated land belonged to the state-owned agricultural enterprises. Their dissolution in 1992 lead to the greatest level of unemployment among rural inhabitants in the whole nation, rising in the Choszczno region to $27-30 \%$ (Michna 2001 and data from Poviat's Labour Offices).

As a result of the dissolution of the state-owned agricultural enterprises, the supply of land in that region was high, facilitating the expansion of private farms. The average size of a farm in the region of Choszczno was 24.5 ha, while in the region of Ostrów Mazowiecka it was 12.8 ha. No deceleration of the menarcheal age in girls from farmer families in the period of crisis, as well as the high acceleration in maturation of girls from this group recorded in 2001, prove that farmers, whose percentage in that region amounted to only $18 \%$, belonged to a privileged socioeconomic group.

In 2001 in the region of Choszczno an exceptional phenomenon was observed - the gradient of menarcheal age reversed its direction (Fig.4). This means that girls from nonfarmer families, who in the years 1967 and 1977 demonstrated the earliest maturation, were found on the opposite extreme of the scale in 2001 - this was the group demonstrating the latest maturation. The girls from farmer families, who in the years 1967 and 1977 demonstrated the latest menarche, showed the earliest maturation in 2001.

This exceptional phenomenon proceeded in two stages. The first stage took place in the decade of economic crisis, when a deceleration of menarcheal age of 0.33 years was noted in girls from the non-farmer group. Landless villagers depended on food 
Table 1. Percentage of girls grouped by: source of family income, number of children in the family, father's and mother's education, in the years of investigation

\begin{tabular}{|c|c|c|c|c|c|c|c|c|c|c|c|c|c|}
\hline \multirow{2}{*}{\begin{tabular}{|c|} 
Regions \\
$\begin{array}{c}\text { Year of investigation } \\
\text { Numbers }\end{array}$
\end{tabular}} & \multicolumn{4}{|c|}{ Choszczno } & \multicolumn{4}{|c|}{ Ostrów Mazowiecka } & \multicolumn{3}{|c|}{ Suwałki } & \multicolumn{2}{|c|}{ Leszno } \\
\hline & $\begin{array}{c}1967 \\
\mathrm{~N}=831\end{array}$ & $\begin{array}{c}1977 \\
N=990\end{array}$ & $\begin{array}{c}1987 \\
N=828\end{array}$ & $\begin{array}{c}2001 \\
N=2354 \\
\end{array}$ & $\begin{array}{c}1967 \\
N=1955\end{array}$ & $\begin{array}{c}1977 \\
N=1918\end{array}$ & $\begin{array}{c}1987 \\
N=2270\end{array}$ & $\begin{array}{c}2001 \\
\mathrm{~N}=2683\end{array}$ & $\begin{array}{c}1977 \\
\mathrm{~N}=2046\end{array}$ & $\begin{array}{c}1987 \\
N=2077\end{array}$ & $\begin{array}{c}2001 \\
\mathrm{~N}=2122\end{array}$ & $\begin{array}{c}1987 \\
N=2094\end{array}$ & $\begin{array}{c}2001 \\
N=2440\end{array}$ \\
\hline \multicolumn{14}{|c|}{ Source of family income } \\
\hline Farmer & 43.0 & 40.0 & 19.0 & 18.0 & 56.0 & 46.0 & 38.0 & 24.0 & 69.0 & 56.0 & 55.0 & 26.0 & 27.0 \\
\hline Farmer-worker & 20.0 & 15.0 & 15.0 & 21.0 & 21.0 & 24.0 & 31.0 & 37.0 & 11.0 & 17.0 & 17.0 & 18.0 & 16.0 \\
\hline Non-farmer & 38.0 & 44.0 & 66.0 & 61.0 & 23.0 & 30.0 & 31.0 & 39.0 & 20.0 & 27.0 & 28.0 & 56.0 & 57.0 \\
\hline \multicolumn{14}{|c|}{ Number of children in the family } \\
\hline $1-2$ children & - & 20.0 & 32.8 & 32.8 & - & 28.1 & 28.1 & 30.6 & 16.1 & 19.0 & 23.8 & 35.0 & 36.9 \\
\hline $3-4$ children & - & 44.0 & 47.6 & 48.4 & - & 48.3 & 48.3 & 50.1 & 47.2 & 48.0 & 48.7 & 49.0 & 50.1 \\
\hline 5 or more children & - & 36.0 & 19.6 & 18.8 & - & 23.6 & 23.6 & 19.3 & 36.7 & 33.0 & 27.6 & 16.0 & $13 ., 0$ \\
\hline \multicolumn{14}{|c|}{ Father's education } \\
\hline Elementary & - & 74.0 & 49.0 & 22.3 & - & 75.5 & 77.5 & 20.8 & 85.1 & 67.0 & 32.7 & 36.0 & 9.7 \\
\hline Vocational & - & 14.0 & 34.4 & 55.1 & - & 12.3 & 13.2 & 59.1 & 6.2 & 20.0 & 43.4 & 54.0 & 67.3 \\
\hline $\begin{array}{c}\text { Secondary and } \\
\text { higher }\end{array}$ & - & 12.0 & 16.6 & 22.6 & - & 12.2 & 12.2 & 20.1 & 8.7 & 13.0 & 23.9 & 10.0 & 23.0 \\
\hline \multicolumn{14}{|c|}{ Mother's education } \\
\hline Elementary & - & 81.3 & 60.8 & 28.3 & - & 80.6 & 80.6 & 17.5 & - & 65.3 & 30.8 & 59.0 & 14.6 \\
\hline Vocational & - & 6.0 & 22.2 & 40.1 & - & 6.3 & 6.3 & 46.7 & - & 15.8 & 28.0 & 27.3 & 52.7 \\
\hline $\begin{array}{c}\text { Secondary and } \\
\text { higher }\end{array}$ & - & 12.7 & 17.0 & 31.6 & - & 13.1 & 13.1 & 35.7 & - & 17.7 & 41.2 & 13.5 & 32.7 \\
\hline
\end{tabular}

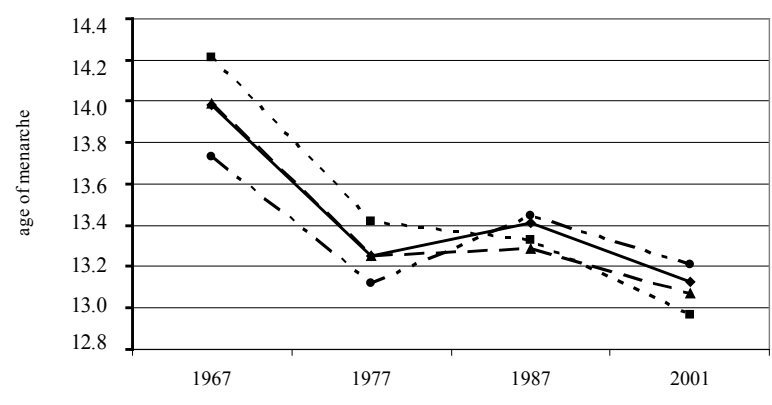

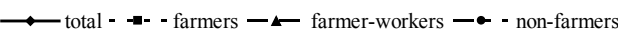

Fig. 4. Average age at menarche of rural girls in the Choszczno region (total) and in daughters from farmer, farmerworker and non-farmer families, in the years 1967, 1977, 1987 and 2001

rationing, similar to urban inhabitants. However, purchasing rationed food in rural areas was much more difficult than in big urban agglomerations. For daughters of farmers, the main food producers at that time, a slight acceleration in maturation was noted. Consequently, in 1987, farmers' daughters had their first menstruation earlier by 0.12 years than girls from landless families. The earlier maturation in this group of girls was recorded only in that region and for the first time since 1967.

A trend of 'compensating for losses' incurred during the crisis was observed in 2001. The greatest acceleration in AM, amounting to 0.36 years, was recorded in girls from farmer families, and their earlier maturation, when compared to girls from non-farmer families, increased to 0.24 years. The acceleration in AM in girls from landless rural families amounted to 0.24 years, but, despite that fact, in 2001 girls from this group had their first menstruation by 0.09 years later than the girls studied in 1977 . Choszczno is the only one of all the four regions under study demonstrating such spectacular biological effects caused by changes in the socio-economic situation of each group of rural inhabitants.

The region of Ostrów Mazowiecka

As follows from the 1997 data, the region was characterized by the lowest GDP per capita as compared to the remaining three regions under study (Report on Social Development, Poland 
MISCELLANEA GEOGRAPHICA - REGIONAL STUDIES ON DEVELOPMENT

Vol. 17 • No. 3 • 2013 • pp. 26-32 • ISSN: 2084-6118 • DOI: 10.2478/v10288-012-0043-0

Table 2. Age at menarche of rural girls from farmer, farmer-worker and non-farmer families in different regions in the period 1967-2001

\begin{tabular}{|c|c|c|c|c|c|c|c|c|c|c|c|c|c|}
\hline \multirow[t]{2}{*}{$\begin{array}{c}\text { Year of } \\
\text { investigation }\end{array}$} & \multicolumn{3}{|c|}{1967} & \multicolumn{3}{|c|}{1977} & \multicolumn{3}{|c|}{1987} & \multicolumn{3}{|c|}{2001} & \multirow[t]{2}{*}{ differences } \\
\hline & $\%$ & mean & SD & $\%$ & mean & SD & $\%$ & mean & SD & $\%$ & mean & SD & \\
\hline groups & \multicolumn{13}{|c|}{ Choszczno } \\
\hline & \multicolumn{3}{|c|}{$N=831$} & \multicolumn{3}{|c|}{$N=990$} & \multicolumn{3}{|c|}{$N=828$} & \multicolumn{3}{|c|}{$\mathrm{N}=2354$} & $2001-1987$ \\
\hline total & 100.0 & 13.98 & 1.30 & 100.0 & 13.25 & 1.19 & 100.0 & 13.41 & 1.15 & 100.0 & 13.13 & 1.95 & $0.28^{*}$ \\
\hline farmer & 43.0 & 14.21 & 1.40 & 40.0 & 13.42 & 1.06 & 19.0 & 13.33 & 1.24 & 18.2 & 12.97 & 1.94 & $0.36^{*}$ \\
\hline farmer-worker & 20.0 & 13.99 & 1.20 & 15.0 & 13.25 & 1.59 & 15.0 & 13.29 & 1.30 & 20.7 & 13.07 & 1.24 & $0.22^{*}$ \\
\hline \multirow[t]{3}{*}{ non-farmer } & 38.0 & 13.73 & 1.30 & 44.0 & 13.12 & 1.15 & 67.0 & 13.45 & 1.08 & 61.1 & 13.21 & 1.80 & $0.24^{*}$ \\
\hline & \multicolumn{13}{|c|}{ Ostrów Mazowiecka } \\
\hline & \multicolumn{3}{|c|}{$N=1955$} & \multicolumn{3}{|c|}{$N=1918$} & \multicolumn{3}{|c|}{$\mathrm{N}=2270$} & \multicolumn{3}{|c|}{$N=2683$} & $2001-1987$ \\
\hline Total & 100.0 & 14.29 & 1.20 & 100.0 & 13.45 & 1.22 & 100.0 & 13.66 & 1.15 & 100.0 & 13.31 & 1.83 & $0.35^{*}$ \\
\hline farmer & 56.0 & 14.45 & 1.20 & 46.0 & 13.71 & 1.30 & 38.0 & 13.80 & 1.18 & 23.8 & 13.44 & 1.55 & $0.36^{*}$ \\
\hline farmer-worker & 21.0 & 14.27 & 1.20 & 24.0 & 13.50 & 0.96 & 31.0 & 13.71 & 1.04 & 37.3 & 13.34 & 1.38 & $0.27^{*}$ \\
\hline \multirow[t]{3}{*}{ non-farmer } & 23.0 & 13.90 & 1.10 & 30.0 & 12.98 & 1.11 & 31.0 & 13.44 & 1.12 & 38.9 & 13.19 & 1.52 & $0.25^{\star}$ \\
\hline & \multicolumn{13}{|c|}{ Suwałki } \\
\hline & \multicolumn{3}{|c|}{-} & \multicolumn{3}{|c|}{$N=2046$} & \multicolumn{3}{|c|}{$\mathrm{N}=2077$} & \multicolumn{3}{|c|}{$N=2122$} & 2001-1987 \\
\hline Total & - & - & - & 100.0 & 13.73 & 1.14 & 100.0 & 13.88 & 1.23 & 100.0 & 13.42 & 1.92 & $0.46^{*}$ \\
\hline farmer & - & - & - & 69.0 & 13.82 & 1.13 & 56.0 & 13.92 & 1.28 & 55.0 & 13.54 & 1.45 & $0.38^{*}$ \\
\hline farmer-worker & - & - & - & 11.0 & 13.62 & 1.12 & 17.0 & 13.80 & 1.02 & 17.0 & 13.30 & 1.31 & $0.50^{*}$ \\
\hline \multirow[t]{3}{*}{ non-farmer } & - & - & - & 20.0 & 13.56 & 1.08 & 27.0 & 13.85 & 1.22 & 28.0 & 13.27 & 1.59 & $0.58^{*}$ \\
\hline & \multicolumn{13}{|c|}{ Leszno } \\
\hline & \multicolumn{3}{|c|}{-} & \multicolumn{3}{|c|}{ - } & \multicolumn{3}{|c|}{$N=2094$} & \multicolumn{3}{|c|}{$\mathrm{N}=2440$} & 2001-1987 \\
\hline Total & - & - & - & - & - & - & 100.0 & 13.18 & 1.21 & 100.0 & 13.04 & 1.52 & $0.14^{*}$ \\
\hline farmer & - & - & - & - & - & - & 26.0 & 13.37 & 1.21 & 27.0 & 13.08 & 1.61 & $0.29^{*}$ \\
\hline farmer-worker & - & - & - & - & - & - & 18.0 & 13.20 & 1.18 & 16.0 & 12.86 & 1.32 & $0.34^{*}$ \\
\hline non-farmer & - & - & - & - & - & - & 56.0 & 13.08 & 1.10 & 57.0 & 13.07 & 1.58 & 0.01 \\
\hline
\end{tabular}

* Difference statistically significant 
2000). This is reflected in the number and quality of durable goods per household, which is the lowest of all the regions under study. Female inhabitants of this region demonstrate the lowest body height and their age at menarche is similar to the latest menarcheal age in girls from the region of Suwałki. The greatest acceleration in maturation (by 0.84 years) was recorded during a period of 'in credit' prosperity, from 1967 to 1977 . In the period of crisis, the greatest deceleration (by 0.46 years) was experienced by girls from landless families, whereas girls from farmer families demonstrated only a slight deceleration, amounting to 0.09 years. In the period 1987- 2001 the acceleration in maturation of girls from farmer families amounted to 0.37 years, while in the non-farmer group it reached 0.25 years.

\section{The region of Suwałki}

The region of Suwałki is located in the north-eastern part of Poland, where the climate is much more severe than in the centre of the country. The roads network is much less developed than in other regions. Poor industrialization makes it harder to find work. Among all four regions under study, this region was characterized by low real income per capita. The predominant farm type in this area is large-scale farms, above 16 ha $(52.7 \%)$. In 2001 the daughters of farmers comprised $55.0 \%$ of total individuals investigated. In all studies, the inhabitants of this region demonstrated the latest age at menarche when compared to girls from all regions under study (Tab.2, Fig.2). The greatest acceleration in maturation, amounting to 0.46 years (and even 0.58 years in the non-farmer group), was recorded in the period 1987-2001. Only a few state-owned agricultural enterprises were situated in this region, so the economic downturn did not affect non-farmers as dramatically as it did in the region of Choszczno.

\section{The region of Leszno}

The region of Leszno is located in the Wielkopolskie Voivodeship, which is an industrialized area with well-developed agriculture and road networks. In 1989 there were 15 stateowned agricultural enterprises operating in this region. Since all of them became privatized, no enterprise underwent dissolution. The former Voivodeship of Leszno (before the administrative reform in Poland) was characterized, in data from 1997, by the highest real income (GDP) per capita of all four regions (Report on Social Development, Poland 2000).

Anthropological measures of socio-economic situation evidenced the greatest body height and earliest maturation of girls (MA 13.04) when compared to the remaining regions.

A marked acceleration in maturation in the period 1987-2001 was recorded in groups depending fully or partially on farming In 2001 the age at menarche of girls from non-farmer families remained the same as 14 years earlier. This proves that even in this most affluent region, land ownership had a positive impact on the economic situation of families after 1989. A lack of acceleration in maturation of girls from non-farmer families demonstrates that the transition period was a difficult time for landless villagers, even in the affluent region of Leszno. In our research covering this region, $57 \%$ of the total number of inhabitants are non-farmers. This group displays better parameters concerning education and a lower number of children per family when compared to farmer families. In the previous research, better education and lower number of children per family were always accompanied by earlier maturation; however, in the year 2001, girls from nonfarmer families in the region of Leszno did not demonstrate this tendency.

In addition, the frequency of overweight and obese inhabitants during the period 1987-2001 reflects significant differences among girls from the regions under study (Chrzanowska et al. 2013). The region of Choszczno proved again to be unusual, as a significantly reduced frequency of overweight and obese female inhabitants was recorded there, which is nowadays very rare. In the regions of Ostrów Mazowiecka and Suwałki the frequency of both parameters increased markedly, which reflects the overall tendency recorded in Poland (Chrzanowska et al. 2007; Chrzanowska \& Suder 2010) and globally (Lobstein et al. 2005). In the region of Leszno both variables demonstrated stability.

\section{Conclusions}

The girls living in four different regions of Poland exhibited marked differences in AM and body height. Age at menarche was attained earliest by girls from the wealthy region (Leszno), both in 1987 and 2001 (13.18 and 13.04 years, respectively). They were also taller than the entire cohort by $0.14 \mathrm{SD}$. The latest AMs were recorded in the comparatively poor region (Suwałki), reaching 13.88 and 13.42 years, respectively (Łaska-Mierzejewska \& Olszewska 2004). In the wealthy region, the differences in AM and body height between girls from the extreme categories, classified by occupation, number of children and educational status, were smaller than in other regions. It could be inferred that the prosperity of a population levels its developmental processes, while poverty or modest living conditions amplify and expose the differentiation.

Poland is an ethnically homogenous country, with no significant national, linguistic or religious minorities. Research by Gronkiewicz (1996), based on 10 independent genetic markers referring to blood groups and eye colour diversity, proved that Poland lacks gradients of social and geographic diversity. Thus, all social and geographic differences in body height or rate of maturation in the studied groups may serve as a reflection of varied living conditions.

\section{References}

Bielicki, T, Waliszko, A, Hulanicka, B \& Koltarz, K 1986, 'Social class gradient in menarchal age in Poland', Annals of Human Biology, vol.13, no 1, pp. 1-11.

Bielicki, T, Szklarska, A, Welon, Z \& Brajczewski, C 1997, Nierówności społeczne w Polsce. Antropologiczne badania poborowych w trzydziestoleciu (1965 - 1995), Monographs 16, Institute of Anthropology, Polish Academy of Sciences, Wrocław

Bielicki, T, Szklarska, A, Kozieł, S \& Welon, Z 2003, Transformacja ustrojowa w Polsce w świetle antropologicznych badań 19 letnich mężczyzn, Monographs 23, Institute of Anthropology, Polish Academy of Sciences, Wrocław

Chrzanowska, M, Kozieł, S \& Ulijaszek, SJ 2007, 'Changes in $\mathrm{BMI}$ and the prevalence of overweight and obesity in children and adolescents in Cracow, Poland, 1971 2000', Economics and Human Biology vol.5, no. 3, pp. 370-378.

Chrzanowska, M \& Suder, A 2010, 'The extent of overweight index in children and adolescents from Cracow, Poland (1971-2000)', Homo - Journal of Comparative Human Biology vol. 61, pp. 453-458.

Chrzanowska, M, Łaska-Mierzejewska, T \& Suder, A 2013, 'Overweight and obesity in rural girls from Poland: changes between 1987 and 2001', Journal of Biosocial Science, vol. 45, pp. 217-229.

De Muinck, Keizer-Schrama, S M P F \& Mul, D 2001, 'Trends in pubertal development in Europe', Human Reproduction Update, vol. 7, no. 3, pp. 287-291. 
Dzun, W 1991, PGR w rolnictwie polskim w latach 1944-1990, PAN IRWiR, Warszawa.

Dzun, W 2002 a, 'Wpływ restrukturyzacji byłych PGR na przemiany w strukturze gospodarstw rolnych', Wieś $i$ Rolnictwo, no.1, pp.152-172.

Dzun, W 2002 b, 'Państwowe gospodarstwa rolne w procesie transformacji ustrojowej', Wieś i Rolnictwo, no. 2, pp.128149.

Godina, E 1994, 'Some latest trends in the somatic development of Moscow school children' in Growth and ontogenetic development in man IV, ed. Hajnis K, Charles University, Prague, pp. 123-127.

Gronkiewicz, L 1996, Różnice społeczne w cechach biologicznych ludności Polski, Monographs 14, Institute of Anthropology, Polish Academy of Sciences.

Henneberg, M \& Louw, GJ 1995, 'Average menarcheal age of higher socioeconomic status urban cape coloured girls assessed by means of status quo and recall methods', American Journal of Physical Anthropology, no. 96, pp. 1-5.

Hulanicka, B 1986, 'O wpływie czynników psychicznych na dojrzałość płciową dziewcząt', Materiały i Prace Antropologiczne, no. 107, pp. 45-80.

Hulanicka, B, Brajczewski, C, Jedlińska, T \& Waliszko, A 1990, City - Town - Village. Growth of Children in Poland in 1988. Monographs 7, Institute of Anthropology, Polish Academy of Sciences, Wrocław.

Hulanicka, B \& Waliszko, A, 1991, 'Deceleration of age at menarche in Poland', Annals of Human Biology, vol. 18, no. 6, pp. 507-513.

Komlos, J, 1994, Stature, Living Standards and Economic Development. Essays in Anthropometric History, The University of Chicago Press.

Liestol, K 1982, 'Social conditions at menareal age: the importance of early years of life' Annals of Human Biology no. 9, pp. 521-537.

Lindgren, GW 1988, 'Auxology - education: some aspects of children's phisical and mental growth in relation to socioeconomic factors in Sweden' Collg. Anthrop. 12, Suppl. 228, Zagreb.

Lobstein, T, Rugny, N \& Leach, R 2005, 'Obesity in Europe - $3^{\text {rd }}$ International Obesity Task Force, Brussels, $15^{\text {th }}$ March.

Łaska-Mierzejewska, T 1970, 'Effect of ecological and socioeconomic factors on the age at menarche, body height and weight of rural girls in Poland', Human Biology, vol. 42, pp. 284-292.

Łaska-Mierzejewska, T 1983, 'Wpływ społecznego zróżnicowania ludności wiejskiej na wiek menarche i jego trend sekularny', Materiały i Prace Antropologiczne, vol. 103, pp. 21-43.
Łaska-Mierzejewska, T \& Łuczak, E 1993, Biologiczne mierniki sytuacji społeczno - ekonomicznej ludności wiejskiej w Polsce w latach 1967, 1977, 1987, Monographs 10, Institute of Anthropology, Polish Academy of Sciences.

Łaska-Mierzejewska, T \& Olszewska, E 2003, Antropologiczna ocena zmian rozwarstwienia społecznego populacji wiejskiej w Polsce w okresie 1967 - 2001 (badania dziewcząt), Studia i Monografie, AWF Warszawa.

Łaska-Mierzejewska, T \& Olszewska, E 2004, 'The maturation rate of girls living in rich and poor rural regions of Poland before and after the transformation of 1989', HOMO Journal of Comparative Human Biology, vol. 55, pp. 129142.

Łaska-Mierzejewska, T \& Olszewska, E 2006, 'Changes in the biological status of Polish girls from a rural region associated with economic and political processes in the period 1967 2001', Journal of Biosocial Science, vol. 38, pp. 187 - 202.

Łaska-Mierzejewska, T \& Olszewska, E 2007, 'Anthropological assessment of changes in living conditions of the rural population in Poland in the 1967 - 2001' Annals of Human Biology, vol. 34, no. 3, pp. $362-376$.

Michna, W 2001, Zatrudnienie $i$ bezrobocie $w$ obszarach wiejskich, IPiSS, Warszawa.

Olszewska, E \& Łaska-Mierzejewska, T 2008, 'Unemployment in the polish countryside and its effect on the development and rate of maturation of rural girls', Anthropological Review, vol. 71, pp. 33-42.

Popczyk, A 1990, Wiek menarche w regionie Warmii i Mazur z uwzględnieniem oddziaływań zmiennych środowiska społeczno - rodzinnego i nałogu nikotynowego rodziców, Praca doktorska, Uniwersytet Wrocławski.

Raport o rozwoju społecznym, Polska 2000. Rozwój obszarów wiejskich 2000, Warszawa.

Sikorska, A 1992, Rodziny bezrolne w strukturze społecznej wsi. Warszawa, Komunikaty Raporty Ekspertyzy, Instytut Ekonomiki Rolnictwa i Gospodarki Żywnościowej.

Stoev, R 1994, 'Sexual maturation in girls from Bulgaria' in Growth and ontogenetic development in man IV, ed. Hajnis K, Charles University, Prague, pp. 197-200.

Yampolskaya, YUA 1994, 'The acceleration of physical development of a human being for the past decades and the prognosis of this process for the next years' in Growth and ontogenetic development in man IV, ed. Hajnis K, Charles University, Prague, pp. 207-217. 